UC-711 and UC-704 Issued: December 1997

Electrodissolution Studies of 304 Stainless

Steel in Sodium Nitrate Electrolyte

Kirk R. Weisbrod

Vincent L. Trujillo

Horacio E. Martinez

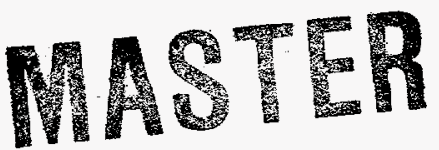

DSTRAUTTON OF THIS DOCUMENT IS UALMATES

$\sqrt{n}$ 


\section{DISCLAIMER}

This report was prepared as an account of work sponsored by an agency of the United States Government. Neither the United States Government nor any agency thereof, nor any of their employees, make any warranty, express or implied, or assumes any legal liability or responsibility for the accuracy, completeness, or usefulness of any information, apparatus, product, or process disclosed, or represents that its use would not infringe privately owned rights. Reference herein to any specific commercial product, process, or service by trade name, trademark, manufacturer, or otherwise does not necessarily constitute or imply its endorsement, recommendation, or favoring by the United States Government or any agency thereof. The views and opinions of authors expressed herein do not necessarily state or reflect those of the United States Government or any agency thereof. 


\section{DISCLAIMER}

Portions of this document may be illegible electronic image products. Images are produced from the best available original document. 


\section{TABLE OF CONTENTS}

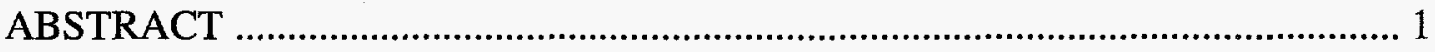

INTRODUCTION

EXPERIMENTAL APPARATUS AND PROCEDURES …………………………... 3

Weld Zone Electrodissolution ........................................................................ 6

CHEMISTRY AND CALCULATIONS ……………….................................... 7

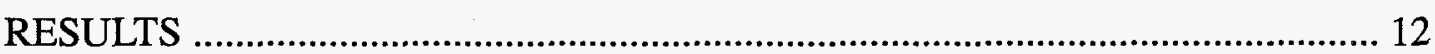

Current Efficiency for Dissolution ................................................................ 12

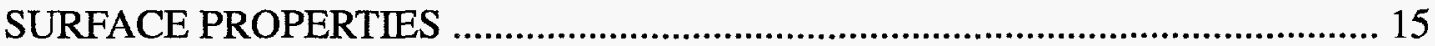

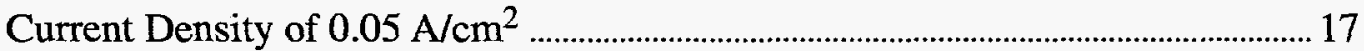

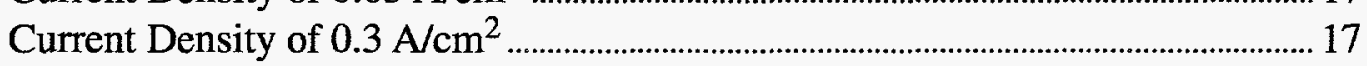

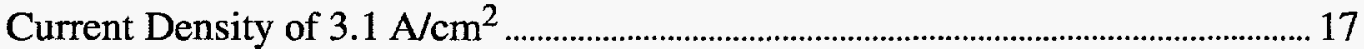

Weld Zone Electrodissolution ........................................................................ 22

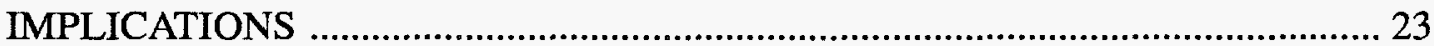

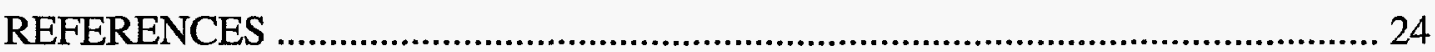




\section{FIGURES}

Fig. 1. Schematic of electrode and TEFLON ${ }^{\mathrm{TM}}$ holder used in $\mathrm{SB}$ and $\mathrm{SC}$ series tests.

Fig. 2. Impact of current density upon current efficiency for dissolution of $304 \mathrm{SS}, \mathrm{pH}=7$ and $10, \mathrm{NaNO}_{3}$ concentration 200 and $600 \mathrm{~g} / \mathrm{L}$.

Fig. 3. Impact of chromium concentration upon current efficiency, $\mathrm{NaNO}_{3}$ concentration is $600 \mathrm{~g} / \mathrm{L}$.

Fig. 4. Goodness of fit comparison between predicted and actual current efficiencies.

Fig. 5(a). SC03 (center of specimen) slight pitting with general etching, grains apparent (x200): $200 \mathrm{~g} / \mathrm{L} \mathrm{NaNO}_{3}$, $\mathrm{pH}=7, \mathrm{Cr}^{+6}=0.01 \mathrm{~g} / \mathrm{L}, 0.05 \mathrm{~A} / \mathrm{cm}^{2}$, stirring rate \#2.

Fig. 5(b). SB05 (center of specimen) hemispherical pitting and some deeper pits, surface etching (x200): $600 \mathrm{~g} / \mathrm{L} \mathrm{NaNO}_{3}$, $\mathrm{pH}=7, \mathrm{Cr}^{+6}=0.01 \mathrm{~g} / \mathrm{L}, 0.05 \mathrm{~A} / \mathrm{cm}^{2}$, stirring rate $\# 2$.

Fig. 5(c). SA02 (center of specimen) numerous hemispherical and deep pits (x200): $600 \mathrm{~g} / \mathrm{L} \mathrm{NaNO}_{3}, \mathrm{pH}=10$, $\mathrm{Cr}^{+6}=0.01 \mathrm{~g} / \mathrm{L}, 0.05 \mathrm{~A} / \mathrm{cm}^{2}$, stirring rate $\# 2$.

Fig. 5(d). SB01 (center of specimen) small pits and general etching (x200): $600 \mathrm{~g} / \mathrm{L} \mathrm{NaNO}_{3}, \mathrm{pH}=10, \mathrm{Cr}^{+6}=12.5 \mathrm{~g} / \mathrm{L}$, $0.05 \mathrm{~A} / \mathrm{cm}^{2}$, stirring rate $\# 2$.

Fig. 6(a). SB03 center of electrode with extensive pitting, little surface etching (x200): $600 \mathrm{~g} / \mathrm{L} \mathrm{NaNO}_{3}, \mathrm{pH}=7$, $\mathrm{Cr}^{+6}=0.02 \mathrm{~g} / \mathrm{L}, 0.3 \mathrm{~A} / \mathrm{cm}^{2}$, stirring rate \#3.

Fig. 6(b). SB04 center of electrode with multiple shallow and deep pits, many 30-60 $\mu \mathrm{M}$ deep, little surface etching (x200): $600 \mathrm{~g} / \mathrm{L} \mathrm{NaNO}_{3}, \mathrm{pH}=7$, $\mathrm{Cr}^{+6}=0.03 \mathrm{~g} / \mathrm{L}, 0.3 \mathrm{~A} / \mathrm{cm}^{2}$, stirring rate $\# 2$.

Fig. 6(c). SC02 center of electrode with surface etching and shallow pitting around $15 \mu \mathrm{M}$ deep $(\mathrm{x} 200)$ : $200 \mathrm{~g} / \mathrm{L} \mathrm{NaNO}_{3}, \mathrm{pH}=7, \mathrm{Cr}^{+6}=0.004 \mathrm{~g} / \mathrm{L}, 0.3 \mathrm{~A} / \mathrm{cm}^{2}$, stirring rate \#2. 
Fig. 6(d). SC07 center of electrode with surface etching and shallow pitting around $15 \mu \mathrm{M}$ deep (x200): $200 \mathrm{~g} / \mathrm{L} \mathrm{NaNO}_{3}, \mathrm{pH}=10, \mathrm{Cr}^{+6}=0.04 \mathrm{~g} / \mathrm{L}$, $0.3 \mathrm{~A} / \mathrm{cm}^{2}$, stirring rate \#2.

Fig. 7(a). SB02 (edge of specimen) electropolished area (x200) $600 \mathrm{~g} / \mathrm{L} \mathrm{NaNO}_{3}, \mathrm{pH}=7, \mathrm{Cr}^{+6}=0.01 \mathrm{~g} / \mathrm{L}$, $3.1 \mathrm{~A} / \mathrm{cm}^{2}$, stirring rate \#2.

Fig. 7(b). SB02 (center of specimen) electropolishing still active in darker area, grain boundaries and hemispherical pits (x200) apparent, conditions same as above.

Fig. 7(c). SA06 (center of specimen) hemispherical pitting, surface etching (x200): $600 \mathrm{~g} / \mathrm{L} \mathrm{NaNO}_{3}, \mathrm{pH}=10$, $\mathrm{Cr}^{+6}=0.004 \mathrm{~g} / \mathrm{L}, 5 \mathrm{~A} / \mathrm{cm}^{2}$, stirring rate \#3.

Fig. 7(d). SC04 (center of specimen) shallow pitting, general etching, and a few deep pits (x200): $200 \mathrm{~g} / \mathrm{L} \mathrm{NaNO}_{3}$, $\mathrm{pH}=7, \mathrm{Cr}^{+6}=0.01 \mathrm{~g} / \mathrm{L}, 3.1 \mathrm{~A} / \mathrm{cm}^{2}$, stirring rate $\# 2$.

Fig. 8. Relative rates of dissolution of whole can and weld zones in sodium nitrate electrolyte. 


\section{TABLES}

Table I. Chemical Composition of 304 SS Samples

(expressed as percent)

Table II. Mechanical Properties of 304 SS Samples 5

Table III. Test Parameters Used During Mass Dissolution from Cans 6

Table IV(a). Series SA Electrodissolution Results 9

Table IV(b). Series SB Electrodissolution Results 10

Table IV(c). Series SC Electrodissolution Results 11

Tables V(a) and (b). Statistical Significance of the Correlation Between Current Efficiency and Independent Variables 15 


\title{
ELECTRODISSOLUTION STUDIES OF 304 STAINLESS STEEL IN SODIUM NITRATE ELECTROLYTE
}

\author{
by \\ Kirk R. Weisbrod \\ Vincent L. Trujillo \\ Horacio E. Martinez
}

\begin{abstract}
To explore the impact of a wide range of operating parameters upon 304 stainless steel (SS) dissolution in sodium nitrate $\left(\mathrm{NaNO}_{3}\right)$ electrolyte, the staff of Engineering Science Applications-Energy and Process Engineering performed a series of beaker experiments. The variables that we explored included $\mathrm{NaNO}_{3}$ concentration, chromate concentration, $\mathrm{pH}$, stirring rate, and current density. We adjusted the run length to obtain approximately $10 \mathrm{mg} / \mathrm{cm}^{2}$ metal removal so that we could compare surface finishes under similar test conditions.
\end{abstract}

Key findings may be summarized as follows. Current efficiency during dissolution depends most strongly upon current density and electrolyte concentration. At $0.05 \mathrm{~A} / \mathrm{cm}^{2}$, current density is more dependent upon chromium concentration than we previously thought. We obtained the best surface finish in a classical electropolishing regime at current densities above $1.5 \mathrm{~A} / \mathrm{cm}^{2}$. Mirror-like finishes were obtained at near $100 \%$ current efficiency.

At $0.05 \mathrm{~A} / \mathrm{cm}^{2}$ we obtained reasonable surface finishes, particularly at lower electrolyte concentration. Current efficiency was low (30\%). At intermediate current densities $\left(0.3 \mathrm{~A} / \mathrm{cm}^{2}\right)$, we obtained the worst surface finishes, that is, surfaces with severe pitting.

Also, we explored preferential attack of the weld zone during electrodissolution of 304 stainless steel cans. Cans were processed with the weld zone shielded and unshielded. Electrodissolution removed approximately twice as much material from cans with unshielded weld zones as from cans with shielded weld zones. Because welds cover 
approximately $6 \%$ of the can area, the depth of metal removal from the welds is 15 times greater than from the remainder of the can.

The following implications are apparent. While operation above $1 \mathrm{~A} / \mathrm{cm}^{2}$ yields the best surface finish at $100 \%$ current efficiency, equipment size and power feed through limitations reduce the attractiveness of this option. The next-best surface finish is obtained at low current densities $\left(0.05 \mathrm{~A} / \mathrm{cm}^{2}\right)$; however, preferential attack of weld zones occurs. Because other Los Alamos researchers, Wedman et al., obtained more favorable results with the sulfate electrolyte, we recommend no further work for the sodium nitrate electrolyte system and that research efforts be concentrated on the sulfate electrolyte system. 


\section{INTRODUCTION}

In support of the Los Alamos National Laboratory (LANL) Plutonium Facility, the staff of Engineering Science Applications-Energy and Process Engineering is developing electrolysis to decontaminate metal surfaces. Cans and gloveboxes made of 304 stainless steel (SS) are cleaned with neutral electrolytes. In this process, dissolved metals precipitate as hydroxides that aid in flocculating actinides removed from the surface during decontamination. A previous effort to decontaminate SS at LANL was described by Wedman et al. ${ }^{1}$

We performed a series of experiments to determine the effect of operating conditions upon current efficiency of metal dissolution with sodium nitrate electrolyte. We explored the conditions of current density, chromium content of the electrolyte, $\mathrm{NaNO}_{3}$ concentration, initial $\mathrm{pH}$, and stirring rate. Also, by varying dissolution times, we were able to investigate the quality of surface finish at similar levels of total metal removal.

In addition, we explored the relative dissolution rate on weld zones. To quantify the effect of enhanced mass removal, we conducted tests with the weld zone both shielded and unshielded. Our attention was focused on total mass removal, current density, and preferential mass dissolution. Significantly more mass removal was observed on the rim of the cans at the two places where the end caps are welded to the cylindrical component than over the remainder of the can surface.

\section{EXPERIMENTAL APPARATUS AND PROCEDURES}

Tests were performed with 304 SS rods with three slightly different compositions. Test series from these specimens are designated as SA, SB, and SC.

To perform beaker tests, we used an AFCBP1 ${ }^{\mathrm{TM}}$ bipotentiostat made by Pine Instruments. The working electrodes were constructed by two methods. For series SA tests, we potted a 1/8-in. 304 SS rod in epoxy. We found that the surface area of the end of the rod was insufficient to obtain accurate weight-loss measures. Subsequently, in series SB and SC we mounted 1/4-in. 304 SS rods in a tightly sealed Teflon ${ }^{\mathrm{TM}}$ tube, as shown in Fig. 1. 


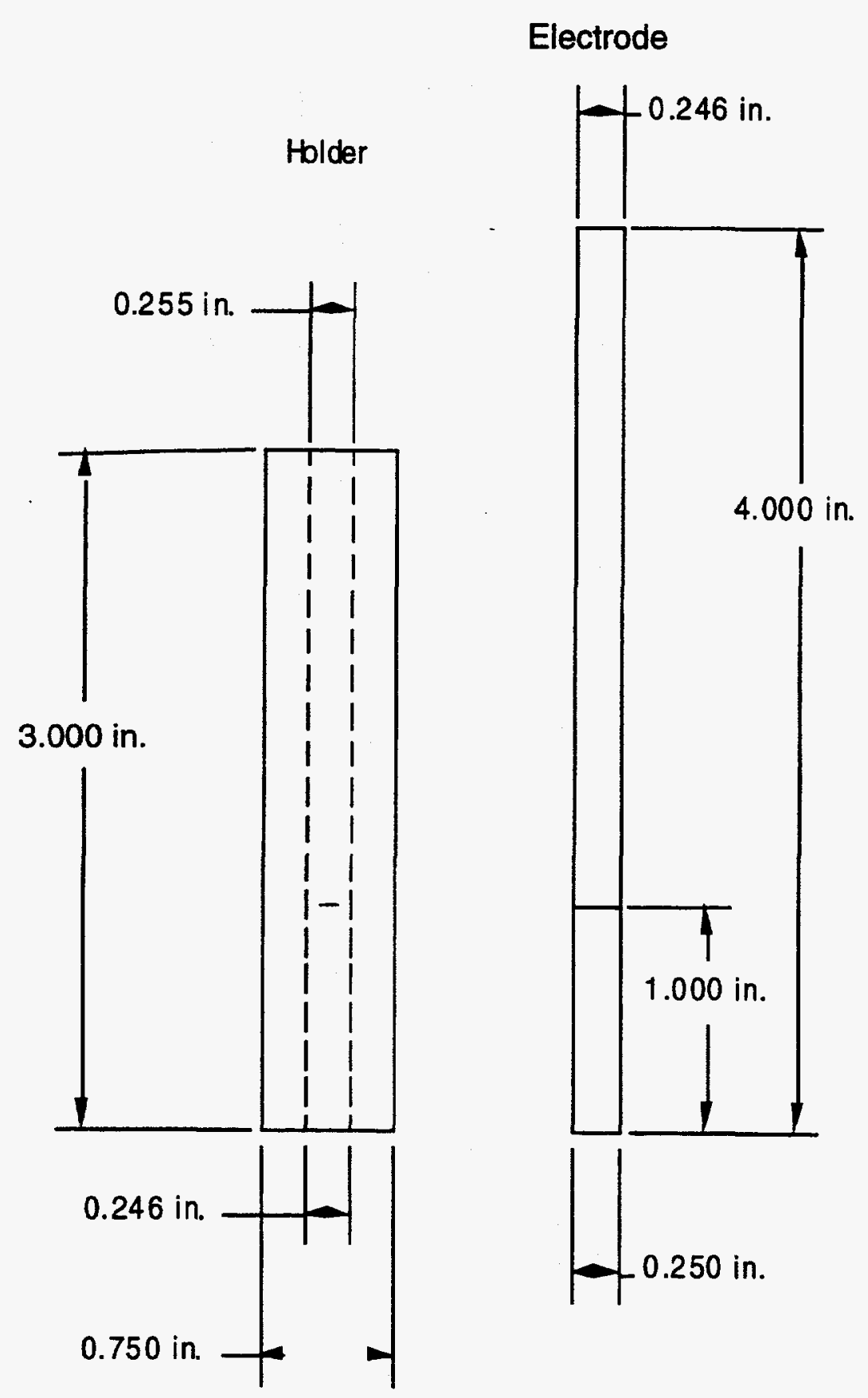

Fig. 1. Schematic of electrode and TEFLON ${ }^{\mathrm{TM}}$ holder used in SB and SC series tests. 
Other cell components consisted of a counter electrode, reference electrode, and $\mathrm{pH}$ electrode. Bath temperature was also measured. A counter electrode consisted of a 1-in.-square platinum flag with platinum wire extension. A double-junction calomel reference electrode aided in essentially eliminating contamination of electrolytes with chloride ions.

We polished the electrode surface wet on an 8 -in. wheel. The electrodes were held during polishing in a specially made 304 SS tube filled with epoxy and with a 1/4-in. hole through the middle that held the electrode perpendicular to the polishing surface. After an initial coarse grinding step with a 240-grit abrasive disk, we used abrasive disks with grits of 400,600 , and 800 , culminating with the use of 1200 -grit disk that yielded a reflective surface.

Next, the sample was weighed and mounted in the TEFLON ${ }^{\mathrm{TM}}$ holder. We filled a $250-\mathrm{ml}$ beaker with $100-\mathrm{ml}$ of electrolyte. Then we placed the electrode assembly $0.5 \mathrm{in}$. away from a 1-in.-long stirring rod. Next, we placed the counter electrode and $\mathrm{pH}$ probe on the side of the beaker. The tip of the reference electrode was placed as close to the working electrode as possible. We monitored the rotation rate of the stirring bar. For instance, at a setting of 2 we obtained a rotation rate of $80 \mathrm{rpm}$. As the stirrer warmed up, we readjusted the rate to $80 \mathrm{rpm}$. By varying the stirring rate and observing the surface finish, we found that the solution agitation was an important variable in the electropolishing regime.

Mill specifications for electrodes used in series SB and SC tests are given in Tables I and II. Sample SC appears to be significantly harder. It contains a higher carbon content, tensile strength, yield stress, and lower elongation at failure.

Table I. Chemical Composition of 304 SS Samples (expressed as percent)

\begin{tabular}{|cccccccccccc|}
\hline Sample & C & Si & Mn & P & S & Ni & Cr & Mo & Cu & N & Co \\
\hline SB & 0.042 & 0.45 & 1.28 & 0.031 & 0.015 & 9.53 & 18.18 & 0.24 & 0.51 & 0.029 & - \\
SC & 0.07 & 0.31 & 1.14 & 0.07 & 0.020 & 8.62 & 18.16 & 0.26 & 0.43 & 0.048 & 0.16 \\
\hline
\end{tabular}

Table II. Mechanical Properties of 304 SS Samples

\begin{tabular}{|cccccc|}
\hline Sample & $\begin{array}{c}\text { Tensile } \\
\text { Strength } \\
(\mathbf{k p s i})\end{array}$ & $\begin{array}{c}\text { Yield } \\
\text { Strength } \\
(\mathbf{k p s i})\end{array}$ & $\begin{array}{c}\text { Elongation } \\
\text { at Failure } \\
(\%)\end{array}$ & $\begin{array}{c}\text { Reduction in } \\
\text { Area } \\
(\%)\end{array}$ & $\begin{array}{c}\text { Hardness, } \\
\text { B rinell Number } \\
\left(\mathbf{k g} / \mathbf{m}^{2}\right)\end{array}$ \\
\hline SB & 104 & 52 & 46 & 77 & 199 \\
SC & 119 & 109 & 36 & 64 & - \\
\hline
\end{tabular}




\section{Weld Zone Electrodissolution}

The relative dissolution rate of weld zones compared with the dissolution rate for the remainder of the can was obtained by first testing a can at a given voltage and measuring the weight loss. We then covered the welds with epoxy and reran the test at the same potential and time. Differences in dissolution indicated losses from the weld zone.

We constructed the cans by fusion welding end caps onto a 4.4-in. diameter by 9.3-in.-long $304 \mathrm{SS}$ tube. We conducted the tests with a solution of sodium nitrate at a concentration of $260 \mathrm{~g} / \mathrm{L}$, a total current of $40 \mathrm{~A}$, and for a 30-min-per-test run. Test parameters are summarized in Table III.

\section{Table III. Test Parameters Used During Mass Dissolution from Cans}

\begin{tabular}{|l|l|}
\hline Cans: & $304-\mathrm{L} \mathrm{SS}$ \\
Material & $4.4 \mathrm{in}$. \\
Diameter & $9.3 \mathrm{in}$. \\
Length & $1037 \mathrm{~cm}^{2}$ \\
Surface Area & Fusion weld \\
Fabrication Method & \\
Electrolyte Solution: & Sodium nitrate $\left(\mathrm{NaNO}_{3}\right)$ \\
Electrolyte & $260 \mathrm{~g} / \mathrm{L}$ \\
Concentration & Average velocity of $5 \mathrm{~cm} / \mathrm{s}$ along can surface \\
Circulation & $40 \mathrm{~A}$ \\
\hline Test Conditions: & $39 \mathrm{~mA} / \mathrm{cm}^{2}$ \\
Total Current & $3.8 \mathrm{~V}$ \\
Current Density & $10.2-11.4$ \\
Average Voltage & $30 \mathrm{~min}$ \\
pH Range & $20-40{ }^{\circ} \mathrm{C}$ \\
Test Duration & \\
Temperature Range &
\end{tabular}

We placed the cans in a fixture that allows the electrolyte to circulate in a closed loop. A more comprehensive description of the fixture set-up and the results of previous tests is given by Martinez. ${ }^{2}$ The fixture forms a concentric cylinder with the can. Insulating spacers are used to maintain a constant gap between the can and the fixture. Current is applied to the can through electrical conductors on both end caps. The can acts as the anode and the fixture acts as the cathode. Solution is introduced at the fixture's lower end cap, flows along the can surface, then leaves the fixture through the end cap on the opposite end. The flow path of the solution is from a reservoir to a centrifugal pump, to the decontamination fixture, and back to the reservoir. The reservoir is open to the atmosphere to allow purging of gases produced during electrolysis. 
The procedure for each test run was as follows:

- measure mass of cans,

- place can in fixture,

- establish solution circulation,

- apply current to $40 \mathrm{~A}$,

- monitor current, voltage, solution temperature, and $\mathrm{pH}$,

- run test for $30 \mathrm{~min}$,

- shut off power,

- remove can from fixture,

- rinse, then dry can, and

- measure mass of can.

The following parameters remained constant in the tests we ran: current density, test duration, flow velocity, and solution concentration. After each run we recorded mass removal.

\section{CHEMISTRY AND CALCULATIONS}

During electrodissolution of 304 SS, decontamination occurs at the anode. Competing anodic reactions are oxygen evolution and reoxidation of chromium that had been reduced at the cathode. Hydrogen evolution is the primary reaction at the cathode. Side reactions include chromium reduction and nitrate reduction. Reactions are given below.

If the $\mathrm{pH}$ is greater than 6.5 , chromate ions are the predominate hexavalent chromium species present.

At the anode the following reactions occur:

$$
\begin{aligned}
& \mathrm{Fe}+3 \mathrm{H}_{2} \mathrm{O} \Rightarrow \mathrm{Fe}(\mathrm{OH})_{3}+3 \mathrm{H}^{+}+3 \mathrm{e}^{-} \\
& \mathrm{Ni}+2 \mathrm{H}_{2} \mathrm{O} \Rightarrow \mathrm{Ni}(\mathrm{OH})_{2}+2 \mathrm{H}^{+}+2 \mathrm{e}^{-} \\
& \mathrm{Cr}+4 \mathrm{H}_{2} \mathrm{O} \Rightarrow \mathrm{CrO}_{4}^{-2}+8 \mathrm{H}^{+}+6 \mathrm{e}^{-}
\end{aligned}
$$

with side reactions

$$
\begin{aligned}
& 2 \mathrm{H}_{2} \mathrm{O} \Rightarrow \mathrm{O}_{2}+4 \mathrm{H}^{+}+4 \mathrm{e}^{-} \\
& \mathrm{Cr}(\mathrm{OH})_{3} \Rightarrow \mathrm{CrO}_{4}^{-2}+3 \mathrm{H}^{+}+3 \mathrm{e}^{-} .
\end{aligned}
$$


At the cathode, the main reaction is:

$$
2 \mathrm{H}^{+}+2 \mathrm{e}^{-} \Rightarrow \mathrm{H}_{2}
$$

with side reactions

$$
\begin{aligned}
& \mathrm{CrO}_{4}^{-2}+3 \mathrm{H}^{+}+3 \mathrm{e}^{-} \Rightarrow \mathrm{Cr}(\mathrm{OH})_{3} \\
& \mathrm{NO}_{3}^{-}+9 \mathrm{H}^{+}+8 \mathrm{e}^{-} \Rightarrow \mathrm{NH}_{3}+3 \mathrm{H}_{2} \mathrm{O} .
\end{aligned}
$$

Although we generally used an alkaline electrolyte, for simplicity the reactions above are given with hydrogen ions. Review of the oxidation reactions indicates that dissolution of iron and nickel is $\mathrm{pH}$ neutral. (This conclusion is obtained, for instance, by adding 2 of reaction [1(a)] to 3 of reaction [3] so that electrons produced are equal to electrons consumed.) Chromium dissolution, however, is a net producer of $\mathrm{H}^{+}$that would make the solution more acidic with time. The decrease in $\mathrm{pH}$ with time is apparent in the experimental results given in Tables IV(a), (b), and (c).

Side reactions at the cathode can make the electrolytes more alkaline. This is particularly true for reaction 4(b), as pointed out by John Huang. ${ }^{3}$ When the cathode is the same size as the anode, reaction 4 (b) dominates over reaction 1(c) and the solution becomes more alkaline in nitrate solutions. Since the cathode area is 40 times greater than the anode, reaction 1 (c) dominates $\mathrm{pH}$ changes in the beaker experiments.

Current efficiency at the anode may be defined as the ratio of current that oxidizes the electrode [reactions $1(\mathrm{a}-\mathrm{c})$ ] to the total current passed by reactions $1(\mathrm{a}-\mathrm{c})$ and reactions 2(a,b). Based upon alloy composition and dissolution of $\mathrm{Fe}, \mathrm{Ni}$, and $\mathrm{Cr}$ to the $+3,+2$, and +6 valence states, 6106 ampere-seconds (coulombs) are equivalent to $1 \mathrm{~g}$ of $304 \mathrm{SS}$. If 16000 ampere-seconds are passed to dissolve $1 \mathrm{~g}$ of alloy, the current efficiency is 0.38 or $38 \%$. Thus, $62 \%$ of the current is used to produce oxygen and oxidize $\mathrm{Cr}^{+3}$ if present.

Once the current efficiency is known for a set of conditions, total mass removal may be calculated as:

$$
\dot{M}\left(\frac{\mathrm{mg}}{\mathrm{cm}^{2}}\right)=9.83 \frac{\eta \mathrm{I}(\mathrm{A}) \mathrm{t}(\mathrm{min})}{\mathrm{S}\left(\mathrm{cm}^{2}\right)}
$$

where $h$ is the current efficiency and $S$ is the electrode surface area. 
Table IV(a). Series SA Electrodissolution Results

SA diameter (in.) $=0.125$

SA surface area $\left(\mathrm{cm}^{2}\right)=0.07913$

Cr content of $304 \mathrm{SS}=0.181$

Date $4 / 16 / 96$

\begin{tabular}{|c|c|c|c|c|c|c|c|c|c|c|c|c|c|c|c|c|}
\hline & & Calc Start & Current & & & & & & & & & & & & Weight & Current \\
\hline Electrode & $\mathrm{NaNO}_{3}$ & $\mathrm{Cr}^{+6}$ & Density & Stirrer & $\mathrm{pH}$ & pH & Time & Time & Time & $W t$ & Wt & Temp & Voltage & Voltage & Removed & Efficiency \\
\hline & $g / L$ & $g / L$ & $\mathrm{~A} / \mathrm{cm}^{2}$ & Setting & Initial & Final & $\min$ & $s$ & total & Initial & Final & ${ }^{\circ} \mathrm{C}$ & Initial & Final & $\mathrm{mg} / \mathrm{cm}^{2}$ & $\%$ \\
\hline SA1 & 600 & 0 & 0.045 & 3 & 10.25 & 10.13 & 53 & 56 & 53.93 & 9.0658 & 9.0648 & 28.7 & 1.75 & & & \\
\hline SA2 & 600 & 0.00181 & $\begin{array}{r}0.5 \\
0.5\end{array}$ & 3 & 10.12 & 10 & 3 & 40 & 3.667 & 9.9573 & 9.9562 & 29.4 & $\begin{array}{r}1.10 \\
1.9\end{array}$ & & 13.94 & 77.2 \\
\hline $\mathrm{SA3}$ & 600 & 0.0038 & 5 & 3 & 9.96 & 9.88 & 0 & 10 & 0.167 & 9.4668 & 9.4655 & 29.6 & & & 16.43 & 200.6 \\
\hline SA4 & 600 & 0 & 0.045 & 3 & 10.11 & 10.05 & 50 & 0 & 50 & 9.5803 & 9.5794 & 27.2 & 1.79 & 1.76 & 11.37 & 51.4 \\
\hline SA5 & 600 & 0.00163 & 0.5 & 3 & 10.03 & 9.87 & 3 & 22 & 3.367 & 9.6578 & 9.6567 & 27.9 & 1.88 & & 13.90 & 84.0 \\
\hline SAG & 600 & 0.00362 & 5 & 3 & 10.04 & 9.98 & 0 & 13 & 0.217 & 9.3107 & 9.3099 & 28.2 & 4.04 & & 10.11 & 95.0 \\
\hline SA7 & 600 & 0.00507 & 5 & 2 & 9.96 & 9.83 & 0 & 13 & 0.217 & 8.0482 & 8.0472 & 24.3 & 6 & & 12.64 & 118.7 \\
\hline SA10 & 600 & 0.00688 & 0.5 & 2 & 10.1 & 9.99 & 3 & 30 & 3.5 & 7.8668 & 7.8655 & 24.5 & 1.87 & & 16.43 & 95.5 \\
\hline SA1 & 600 & 0.00923 & 0.1 & 2 & 10.12 & 10.07 & 13 & 0 & 13 & 9.0289 & 9.028 & 25 & 1.94 & & 11.37 & 89.0 \\
\hline SA2 & 600 & 0.01086 & 0.05 & 2 & 10.03 & 9.97 & 50 & 0 & 50 & 9.9132 & 9.9127 & 25.2 & 1.85 & 1.81 & 6.32 & 25.7 \\
\hline SA2 & 600 & 0.01176 & 0.05 & 2 & 10.02 & & 50 & 43 & 50.72 & 9.9127 & 9.9111 & 26.6 & 1.85 & & 20.22 & 81.1 \\
\hline SA3 & 600 & 0.01466 & 1 & 0 & 9.98 & & 1 & 5 & 1.083 & 9.4249 & 9.424 & 27.5 & $2.08-3.8$ & 2.3 & 11.37 & 106.8 \\
\hline SA9 & 600 & 0.01629 & 1 & 2 & 10 & 27.4 & 1 & 5 & 1.083 & 9.2644 & 9.2634 & & 2.1 .3 & 2.34 & 12.64 & 118.7 \\
\hline SAB & 600 & 0.0181 & 2 & 2 & 10.03 & & 0 & 32 & 0.533 & 9.3889 & 9.3878 & 27.7 & 6.07 & 3.3 & 13.90 & 132.6 \\
\hline
\end{tabular}


Table IV(b). Series SB Electrodissolution Results

$\mathrm{SB}$ diameter $($ in. $)=0.25$

SB surface area $\left(\mathrm{cm}^{2}\right)=0.316$

Cr content of $304 \mathrm{SS}=0.182$

Date 5/21/96

\begin{tabular}{|c|c|c|c|c|c|c|c|c|c|c|c|c|c|c|c|c|}
\hline & & Calc Start & Current & & & & & & & & & & & & Weight & Current \\
\hline \multirow[t]{3}{*}{ Electrode } & $\mathrm{NaNO}_{3}$ & $\mathrm{Cr}^{+6}$ & Density & Stirrer & $\mathrm{pH}$ & $\mathrm{pH}$ & Time & Time & Time & $W_{t}$ & $W t$ & Temp & Voltage & Voltage & Removed & Efficiency \\
\hline & $g / L$ & $g / L$ & $\mathrm{~A} / \mathrm{cm}^{2}$ & Setting & Initial & Final & $\min$ & s & total & Initial & Final & ${ }^{\circ} \mathrm{C}$ & Initial & Final & $\mathrm{mg} / \mathrm{cm}^{2}$ & $\%$ \\
\hline & & & & & & & & & & & & & & & & SB Series \\
\hline SB1 & 600 & 0 & 1 & 2 & 8.8 & 7.23 & 1 & 0 & 1 & 23.9477 & 23.9446 & 25.8 & 3 & & 9.79 & 99.7 \\
\hline SB2 & 600 & 0.01164 & 3.096 & 2 & 7.07 & 6.49 & 0 & 31 & 0.517 & 25.2091 & 25.204 & 26.5 & 8 & 5 & 16.11 & 102.5 \\
\hline SB3 & 600 & 0.02309 & 0.3 & 3. & 6.8 & 6.53 & 4 & 67 & 5.117 & 25.1075 & 25.1045 & 26.9 & 1.99 & & 9.48 & 62.8 \\
\hline SB4 & 600 & 0.02636 & 0.3 & 2 & 6.59 & 6.19 & 3 & 25 & 3.417 & 25.1892 & 25.1861 & 27.2 & 1.96 & & 9.79 & 97.2 \\
\hline SB5 & 600 & 0.00564 & 0.05 & 2 & 7.49 & 7.04 & 50 & 0 & 50 & 24.0062 & 24.003 & 25.2 & 1.64 & & 10.11 & 41.2 \\
\hline SB6 & 600 & 2 & 1 & 2 & 7 & 6.97 & 1 & & 1 & 23.4939 & 23.4908 & 27.1 & 2.82 & & 9.79 & 99.7 \\
\hline SB7 & 600 & 2 & 0.05 & 2 & 7 & 7.14 & 50 & 0 & 50 & 23.7095 & 23.7066 & 27.5 & 1.66 & 1.7 & 9.16 & 37.3 \\
\hline SB8 & 600 & 2 & 0.3 & 2 & 7.03 & 7.15 & 3 & 23 & 3.383 & 23.4544 & 23.4515 & 28.2 & 1.95 & 2 & 9.16 & 91.9 \\
\hline SB9 & 600 & 2 & 3.096 & 2 & 7.13 & 7.11 & 0 & 19 & 0.317 & 23.334 & 23.3312 & 28.3 & 8 & 5 & 8.85 & 91.8 \\
\hline SB10 & 600 & 2 & 0.05 & 2 & 10.97 & 10.97 & 53 & 16 & 53.27 & 23.6971 & 23.6933 & 22.5 & 1.73 & & 12.01 & 45.9 \\
\hline SB+1 & 600 & 2 & 0.3 & 2. & 10.91 & & 3 & 27 & $\begin{array}{r}3.45 \\
\end{array}$ & 21.7924 & 21.7891 & 22.8 & 2.01 & & 10.43 & 102.5 \\
\hline $\mathrm{SB} 12$ & 600 & 2 & 3.096 & 2 & 10.93 & & 0 & 20 & 0.333 & 23.6445 & 23.6412 & 23.3 & 8 & 4. & 10.43 & 102.8 \\
\hline SB13 & 600 & 12.5 & 3.096 & 2 & 7.02 & & 0 & 19 & 0.317 & 23.7094 & 23.7062 & 24.5 & 8 & 5 & 10.11 & 104.9 \\
\hline SB+4 & 600 & 12.5 & 0.3 & 2 & 7.01 & & 3 & 24 & 3.4 & 23.6098 & 23.607 & 24.6 & 2.02 & & 8.85 & 88.3 \\
\hline SB15 & 600 & 12.5 & 0.05 & 2 & 7 & 6.99 & 156 & 58 & 157 & 23.6644 & 23.6603 & 24 & 1.7 & & 12.95 & 16.8 \\
\hline SB1 & 600 & 12.5 & 0.05 & 2 & 10.92 & 10.89 & 241 & 0 & 241 & 23.902 & 23.8986 & 24.7 & 1.68 & & 10.74 & 9.1 \\
\hline SB16 & 600 & 12.5 & 0.3 & 2 & 10.7 & & 3 & 40 & 3.667 & 23.4679 & 23.4646 & 25.1 & 2.06 & & 10.43 & 96.5 \\
\hline
\end{tabular}


Table IV(c). Series SC Electrodissolution Results

$S C$ diameter (in.) $=0.25$

SC surface area $\left(\mathrm{cm}^{2}\right)=0.316$

Cr content of $304 \mathrm{SS}=0.182$

Date 6/13/96

\begin{tabular}{|c|c|c|c|c|c|c|c|c|c|c|c|c|c|c|c|c|}
\hline & & Starting & Current & & & & & & & & & & & & Weight & Current \\
\hline Electrode & $\mathrm{NaNO}_{3}$ & $\mathrm{Cr}^{+6}$ & Density & Stirrer & $\mathrm{pH}$ & $\mathrm{pH}$ & Time & Time & Time & $W t$ & Wt & Temp & Voltage & Voltage & Removed & Efficiency \\
\hline & $g / L$ & $g / L$ & $\mathrm{~A} / \mathrm{cm}^{2}$ & Setting & Initial & Final & $\min$ & $s$ & total & Initial & Final & ${ }^{\circ} \mathrm{C}$ & Initial & Final & $\mathrm{mg} / \mathrm{cm}^{2}$ & $\%$ \\
\hline & & & & & & & & & & & & & & & & SC Series \\
\hline $\mathrm{SCl}$ & 200 & 0 & 0.3 & 2 & 8.7 & 8.15 & 3 & 56 & 3.933 & 22.7509 & 22.7489 & 23 & 2.44 & & 6.32 & 54.5 \\
\hline SC2 & 200 & 0.0069 & 0.3 & 2 & 7.4 & 6.18 & 12 & 0 & 12 & 22.9047 & 22.9016 & 23.5 & 2.8 & & 9.79 & 27.7 \\
\hline SC3 & 200 & 0.01253 & 0.05 & 2 & 6.9 & 6.34 & 53.02 & 0 & 53.02 & 22.7361 & 22.7335 & 24.6 & 1.74 & 1.9 & 8.21 & 31.5 \\
\hline $\mathrm{SCA}$ & 200 & 0.01725 & 3.096 & 2 & 7.2 & 6.9 & 0 & 20 & 0.333 & 22.8937 & 22.8906 & 25.6 & 6.6 & & 9.79 & 96.6 \\
\hline SC5 & 200 & 0.02288 & 3.096 & 0 & 6.9 & 6.3 & $\underline{0}$ & 19 & 0.317 & 22.8132 & 22.81 & 26.2 & 6 & & 10.11 & 104.9 \\
\hline SC6 & 200 & 0.02869 & 3.096 & 2 & 10.44 & 10.12 & 0 & 20 & 0.333 & 23.525 & 23.5217 & 26.3 & 6.6 & & 10.43 & 102.8 \\
\hline SC7 & 200 & 0.03505 & 0.3 & 2 & 10.32 & 10.18 & 12 & 0 & 12 & 22.7016 & 22.6988 & 26.6 & 2.3 & 2.6 & 8.85 & 25.0 \\
\hline SC8 & 200 & 0.0365 & 0.05 & 2 & 10 & 9.68 & 64 & 33 & 64.55 & 22.6403 & 22.6379 & 26.9 & 1.72 & & 7.58 & 23.9 \\
\hline SC9 & 34 & 0 & 0.3 & 2 & 10 & 9.28 & 54 & 69 & 55.15 & 22.7512 & 22.7481 & 26 & 4 & & 9.79 & 6.0 \\
\hline SC10 & 34 & 0.00563 & 1.26 & 2 & 10.1 & 9.5 & 4 & 57 & 4.95 & 22.6403 & 22.6379 & 27.5 & 1.72 & & 7.58 & 12.4 \\
\hline SC11 & 34 & 0.00999 & 0.05 & 2 & 10.2 & 9.44 & 232 & 106 & 233.8 & 22.6403 & 22.6379 & 27.5 & 1.72 & & 7.58 & 6.6 \\
\hline
\end{tabular}




\section{RESULTS}

The conditions that we explored were current density, chromium content of the electrolyte, $\mathrm{NaNO}_{3}$ concentration, initial $\mathrm{pH}$, and stirring rate. Tables IV(a), (b), and (c) give operating conditions, total metal weight loss, and calculated current efficiency. Microscopic observations are also described.

\section{Current Efficiency for Dissolution}

Review of Tables IV(a), (b), and (c) indicates that current efficiency is most dependent upon current density and sodium nitrate concentration. As the current density increases, the current efficiency rises to $100 \%$ at high electrolyte concentration (Fig. 2).

Values greater than $100 \%$ reflect the $\pm 5 \%$ error in weight measurements that were input to current efficiency calculations. Because the current efficiency calculation assumes a solution valence state for each metal species, dissolution to a lower valence state can also yield current efficiencies greater than $100 \%$. No oxygen evolution is observed at $100 \%$ current efficiency. At greater than $1 \mathrm{~A} / \mathrm{cm}^{2}$, electropolishing becomes apparent at the edge of the electrode where the local current density is highest.

We also observed that the current efficiency is lower for lower electrolyte concentrations. At $34 \mathrm{~g} / \mathrm{L}$, which corresponds to $0.4 \mathrm{M}$, the current efficiency is about $10 \%$. This is approximately the same ionic strength as the $0.2 \mathrm{M} \mathrm{Na}_{2} \mathrm{SO}_{4}$ solution that we are currently exploring.

Early work by Hoare and others on the properties of passive films helps to explain a lower current efficiency at lower ionic strength. ${ }^{4} \mathrm{~A}$ good protective film is an electronic conductor that allows passage of current only by oxidizing water to oxygen gas. The ion-replacement model suggests that when the oxide matrix is attacked by anions, it exhibits ionic conductivity that results in metal dissolution; thinning of the oxide layer was also reported. ${ }^{5}$ Thus, higher current densities associated with higher field gradients across the passive layer will increase anion penetration and dissolution. Higher anion concentrations will also increase the rate of attack and thus the current efficiency for metal dissolution. 


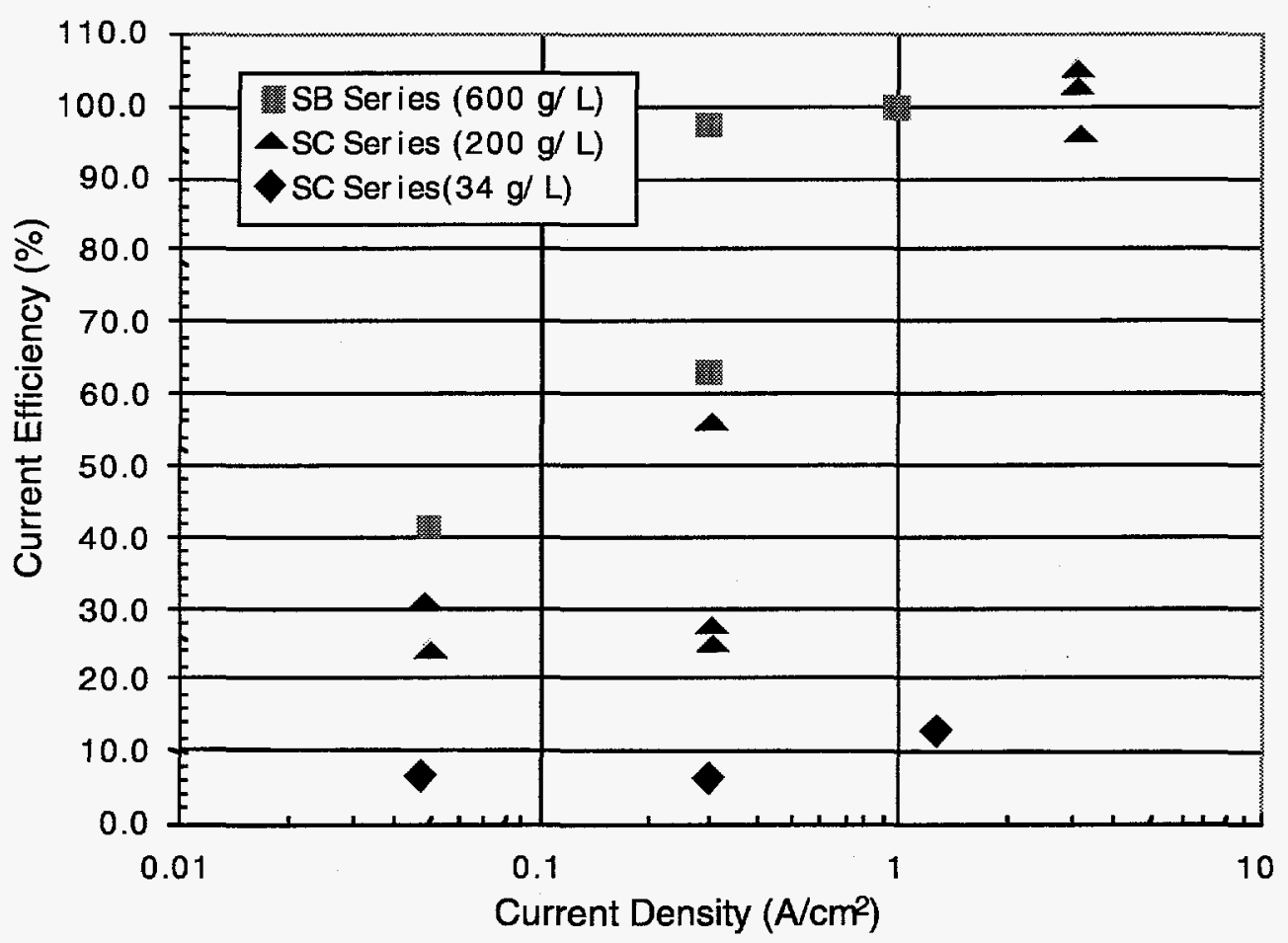

Fig. 2. Impact of current density upon current efficiency for dissolution of $304 \mathrm{SS}$, $\mathrm{pH}=7$ and 10, $\mathrm{NaNO}_{3}$ concentration 200 and $600 \mathrm{~g} / \mathrm{L}$.

We explored the effect of chromium content of the electrolyte upon current efficiency (Fig 3). Earlier work by Childs and Winkel showed a decrease in current efficiency with increased chromium content of the electrolyte. ${ }^{6}$ We were interested in confirming trends for our concentration range and current densities. Therefore, we explored chromium concentrations up to $12.5 \mathrm{~g} / \mathrm{L}$. These concentrations correspond to cleaning 10 cans with a system electrolyte volume of $4.5 \mathrm{~L}$.

At $0.05 \mathrm{~A} / \mathrm{cm}^{2}$, the current efficiency dropped by more than $50 \%$. At high current densities, we saw little change in current efficiency with concentration. Results at higher current density agree with those of Childs and Winkel. ${ }^{6}$ Because $\mathrm{Cr}(\mathrm{OH})_{3}$ is insoluble in alkaline solutions, chromium oxidation back to the $\mathrm{Cr}^{+6}$ at the anode may not be responsible for the loss in current efficiency. Instead, formation of a chrome-rich oxide layer that improves electronic conductivity of the oxide layer, may enhance oxygen evolution. Because a low current density is all that is currently obtainable in the can decontamination work, greater attention needs to be paid to the chromium content of the electrolyte than we had previously thought. 


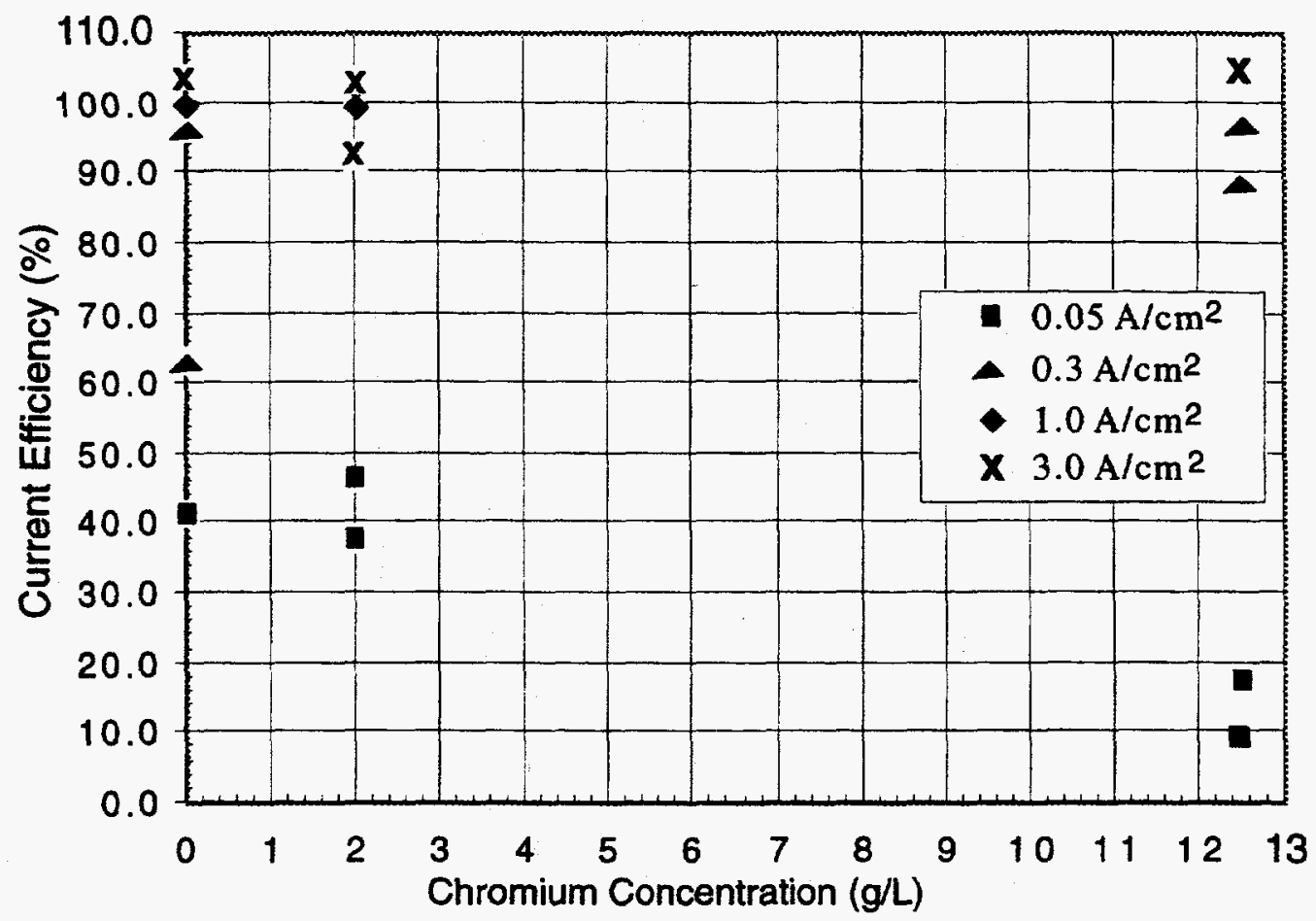

Fig. 3. Impact of chromium concentration upon current efficiency, $\mathrm{NaNO}_{3}$ concentration is $600 \mathrm{~g} / \mathrm{L}$.

In order to derive a correlation and determine the level of significance for each parameter, we applied a stepwise multivariable regression to the current density results. The best correlation was as follows:

$$
\mathrm{CE}=-0.568+0.403 \log (\mathrm{i})+0.567 \log \left(\mathrm{C}_{\mathrm{NaNO}_{3}}\right)
$$

where the goodness of fit is described by Tables V(a) and (b) below. 
Tables V(a) and (b). Statistical Significance of the Correlation Between Current Efficiency and Independent Variables

\begin{tabular}{|c|cccc|}
\hline Source & $\begin{array}{c}\text { Sum of } \\
\text { Squares }\end{array}$ & Differential & Mean Square & F-ratio \\
\hline Regression & 5.23682 & 2 & 2.61841 & 53.9 \\
Residual & 1.89603 & 39 & 0.048616 & \\
\hline
\end{tabular}

\begin{tabular}{|c|rccc|}
\hline Variable & Coefficient & $\begin{array}{c}\text { Standard Error } \\
\text { of Coefficient }\end{array}$ & T-ratio & Probability \\
\hline Constant & -0.567843 & 0.2570 & -2.21 & 0.0331 \\
$\log " \mathrm{i} "$ & 0.402977 & 0.0481 & 8.37 & $\leq 0.0001$ \\
$\log \left(\mathrm{NaNO}_{3}\right)$ & 0.566509 & 0.0975 & 5.81 & $\leq 0.0001$ \\
\hline
\end{tabular}

Predicted efficiencies in contrast to the actual current efficiencies are plotted in Fig. 4. The scatter in the fit indicates the error in weight measurements that was especially apparent in data from series SA. Chromium concentration and $\mathrm{pH}$ were initially included in the correlation but they did not improve the fit significantly. For instance, when chromium concentration was added, the F-ratio actually went down; indicating that the better fit did not justify including the additional parameter.

Wedman et al. also found that higher current densities and electrolyte concentrations increase current efficiency. ${ }^{1}$ Because Wedman et al. explored a wider $\mathrm{pH}$ range, they observed higher current efficiencies in acidic solutions. In contrast, because we investigated a narrower $\mathrm{pH}$ range, we saw little effect.

\section{SURFACE PROPERTIES}

We took surface micrographs of each electrode at 200 times magnification and ran samples for sufficient time so that a similar average metal removal was obtained for each sample. Thus, micrographs have a common basis. Because current densities are higher at the edge of the samples than in the middle, two pictures were taken for each specimen. 
In order to quantify the variation in current density across the electrode surface, Newman solved the applicable set of equations for the current distribution across a rotating disk electrode. ${ }^{7}$ The electrode configuration applied in this study has the same geometry as a rotating electrode. If the current distribution is determined only by solution resistance, the current density at the center of the circle is half the average and approaches infinity at the edge. Both kinetic resistance and mass-transfer limitations create a more uniform current distribution.

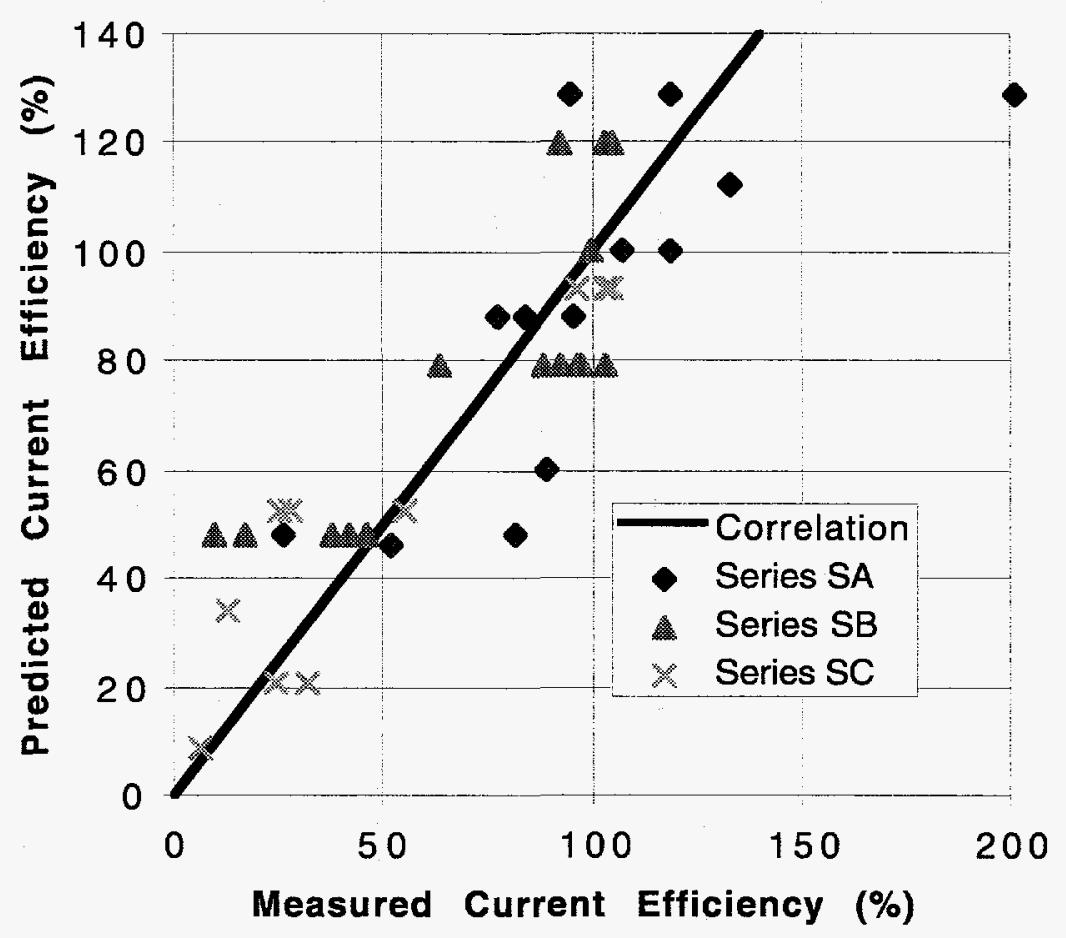

Fig. 4. Goodness of fit comparison between predicted and actual current efficiencies.

The applicable dimensionless group for describing the transition from ohmic control toward a uniform current distribution caused by kinetic resistance is

$$
\mathrm{J}=\left(\alpha_{\mathrm{a}}+\alpha_{\mathrm{c}}\right) \frac{\mathrm{i}_{\mathrm{o}} \mathrm{Fr}_{\mathrm{a}}}{\mathrm{RT} \kappa}
$$

where

$$
\begin{array}{ll}
\mathrm{a}= & \text { charge transfer coefficients, } \\
\mathrm{i}_{\mathrm{o}}= & \text { exchange current density, } \mathrm{A} / \mathrm{cm}^{2}, \\
\mathrm{r}_{\mathrm{o}}= & \text { electrode radius, } \mathrm{cm}, \\
\mathrm{K}= & \text { solution conductivity, } \mathrm{S} / \mathrm{cm}, \\
\mathrm{F}= & \text { Faraday constant }(96500 \mathrm{C} / \mathrm{g} \text {-equiv), } \\
\mathrm{R}= & \text { ideal gas constant, and } \\
\mathrm{T}= & \text { temperature, } \mathrm{K} .
\end{array}
$$


As J becomes larger, the current distribution becomes more nonuniform. For the following discussion, greater current density variations are expected for more reversible surface reactions on larger electrodes in more dilute electrolytes. At this time, measurements of $a$ and $i_{o}$ are not available to evaluate Eq. 7.

Surface observations are discussed below at three current densities: $0.05,0.3$, and $3.1 \mathrm{~A} / \mathrm{cm}^{2}$. Generally, these three levels summarize the full range of behavior that we observed.

\section{Current Density of $0.05 \mathrm{~A} / \mathrm{cm}^{2}$}

Etching characteristics at $0.05 \mathrm{~A} / \mathrm{cm}^{2}$ are summarized in Fig. 5. For $200 \mathrm{~g} / \mathrm{L} \mathrm{NaNO}$, Fig. 5(a) illustrates surface etching where the grain structure is apparent as regions with parallel lines or steps. Relatively few pits are apparent. When electrolyte concentration is increased to $600 \mathrm{~g} / \mathrm{L}$, the current efficiency rises from $30 \%$ to $50 \%$. Surface pitting, however, becomes more predominant [Fig. 5(b)].

Effects of other changes in electrolyte composition may also be explored. Comparison of Figs. $5(\mathrm{~b})$ and(c) shows that a $\mathrm{pH}$ change from 7 to 10 causes little change in surface character. Increasing the chromium concentration from essentially zero to $12.5 \mathrm{~g} / \mathrm{L}$ decreases the current efficiency but improves surface properties, as shown in Fig. 5(d).

\section{Current Density of $0.3 \mathrm{~A} / \mathrm{cm}^{2}$}

When the average current density increases to $0.3 \mathrm{~A} / \mathrm{cm}^{2}$, pitting increases markedly. In addition, surface etching appears to decrease because surface scratches from polishing become more apparent [Fig. 6(a)]. As stirring decreases, pitting becomes widespread [Fig. 6(b)]. As the electrolyte concentration decreases from 600 to $200 \mathrm{~g} / \mathrm{L}$, surface etching is enhanced [Fig. 6(c)], but at the expense of lower current efficiency ( $30 \%$ compared with $100 \%$ ). Finally, a pH change from 7 to 10 appears to have little effect upon surface appearance [Fig. 6(d)].

\section{Current Density of $3.1 \mathrm{~A} / \mathrm{cm}^{2}$}

At high current densities, a classical electropolishing regime is attained. Datta and Landolt also found that electropolishing in nitrate solutions required high current densities. ${ }^{8}$ It is generally accepted that classical electropolishing develops when a salt film is formed on the electrode surface. Salt film occurs at lower current densities in phosphate electrolytes with low solubility of iron phosphate. Lower mass transport and lower temperatures also tend to encourage salt film formation.

Characteristics of electropolishing are seen in Fig. 7(a). A mirror-like finish is produced. Under some conditions, preferential dissolution at grain boundaries is apparent, along with the formation of shallow hemispherical pits [Fig. 7(b)]. Electropolishing is also characterized by a current efficiency of unity. 
At $3 \mathrm{~A} / \mathrm{cm}^{2}$ variations in system parameters can move the electrode out of the electropolishing regime. When the rate of stirring is increased from a setting of \#2 to \#3 on the dial, surface etching and aggressive hemispherical pitting become apparent [Fig. 7(c)]. In addition, when the electrolyte concentration decreases from 600 to $200 \mathrm{~g} / \mathrm{L}$, severe pitting and general etching occur similar to what we observed at $0.3 \mathrm{~A} / \mathrm{cm}^{2}$ [Fig. 7(d)].

Stirring affects electropolishing by the following mechanism. An increase in stirring improves mass transport from the electrode surface. When the ferric nitrate falls below saturation, the salt film dissolves and electropolishing ceases.

A higher electrolyte concentration favors electropolishing in two ways. According to Eq. 7, a higher conductivity will increase the current density at the middle of the sample for the same average current density. A higher rate of dissolution increases ferric nitrate concentration at the central area to increase the size of the region where electropolishing can occur. In addition, solubility of ferric nitrate is dependent upon nitrate concentration in solution. As the nitrate concentration increases, ferric nitrate solubility decreases, thus favoring salt film formation.

These results may be compared with the findings reported by Wedman et al. who observed greater surface roughening for current densities above $0.1-0.2 \mathrm{~A} / \mathrm{cm}^{2}{ }^{1}$ This is in general agreement with the higher pitting that we saw in this study at $0.3-0.5 \mathrm{~A} / \mathrm{cm}^{2}$ compared with $0.05 \mathrm{~A} / \mathrm{cm}^{2}$. Wedman et al. reported no measurements at $0.05 \mathrm{~A} / \mathrm{cm}^{2}$ in neutral-to-alkaline solution to compare with our results. Also, Wedman et al. did not make measurements above $0.5 \mathrm{~A} / \mathrm{cm}^{2}$, the level at which classical electropolishing is encountered. Thus, inconsistencies between the two studies may be attributed to measurements made under different conditions. 


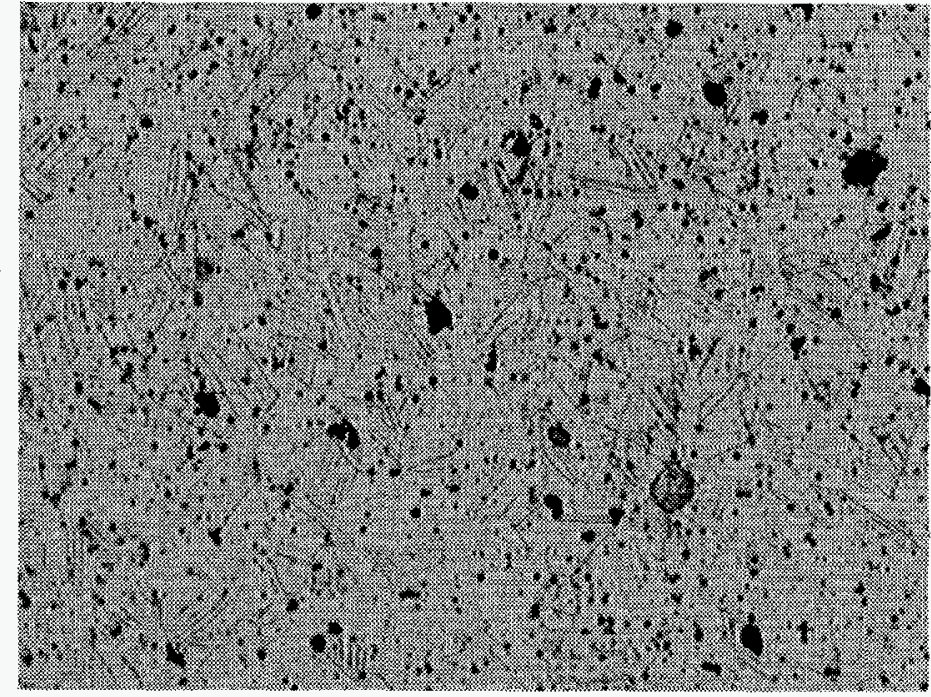

Fig. 5(a). SC03 (center of specimen) slight pitting with general etching, grains apparent (x200): $200 \mathrm{~g} / \mathrm{L} \mathrm{NaNO}_{3}, \mathrm{pH}=7$,

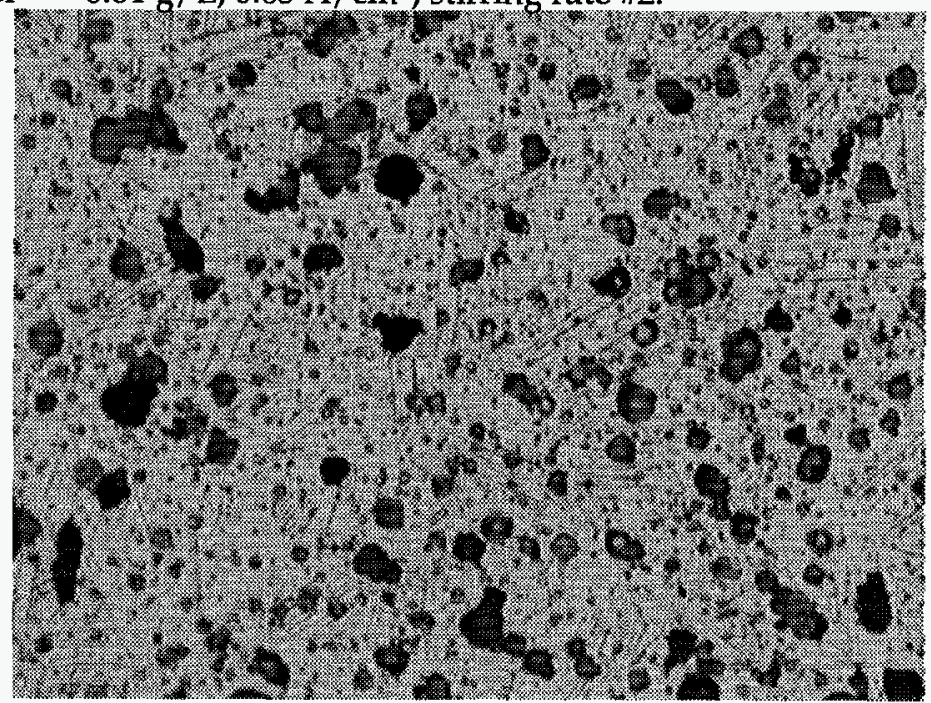

Fig. 5(b). SB05 (center of specimen) hemispherical pitting and some deeper pits, surface etching (x200): $600 \mathrm{~g} / \mathrm{L} \mathrm{NaNO}{ }_{3}, \mathrm{pH}=7$, $\mathrm{Cr}^{+6}=0.01 \mathrm{~g} / \mathrm{L}, 0.05 \mathrm{~A} / \mathrm{cm}^{2}$, stirring rate $\# 2$.

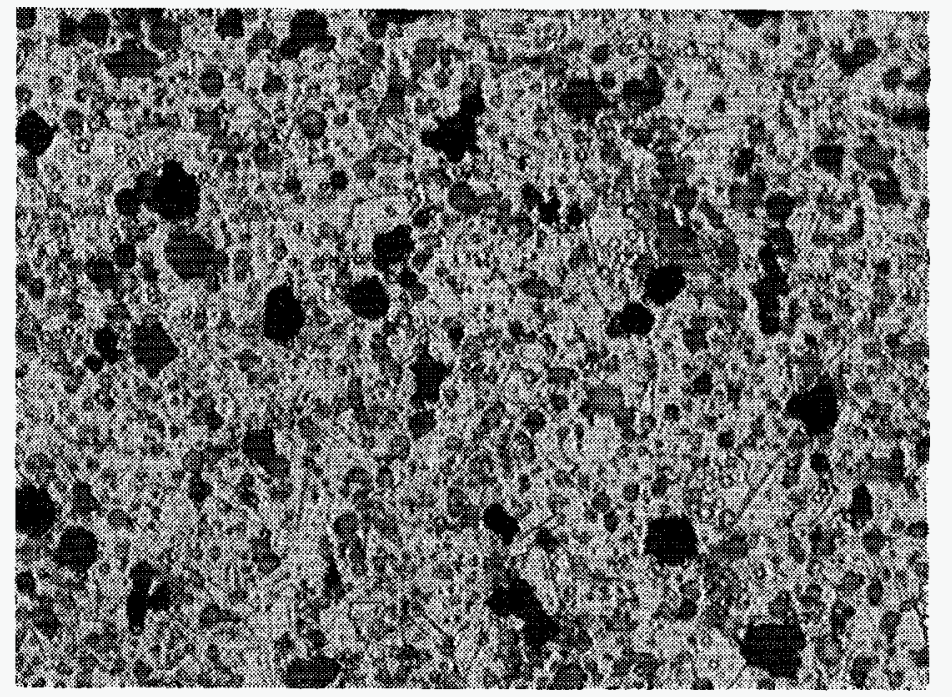

Fig. 5(c). SA02 (center of specimen) numerous hemispherical and deep pits (x200): $600 \mathrm{~g} / \mathrm{L} \mathrm{NaNO}_{3}, \mathrm{pH}=10, \mathrm{Cr}^{+6}=0.01 \mathrm{~g} / \mathrm{L}$, $0.05 \mathrm{~A} / \mathrm{cm}^{2}$, stirring rate $\# 2$.

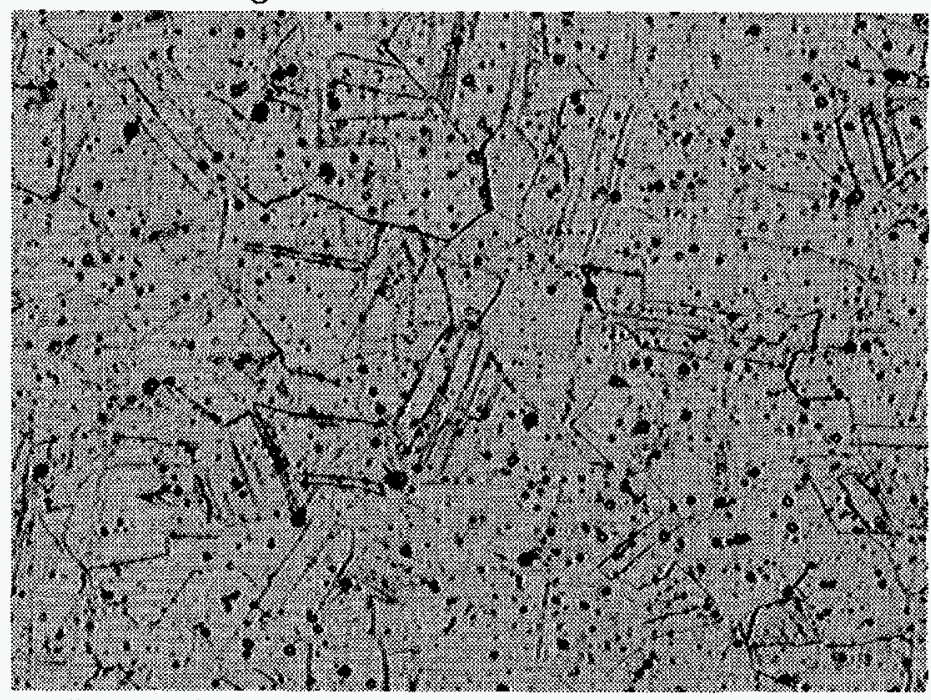

Fig. 5(d). SB01 (center of specimen) small pits and general etching (x200): $600 \mathrm{~g} / \mathrm{L} \mathrm{NaNO}_{3}, \mathrm{pH}=10, \mathrm{Cr}^{+6}=12.5 \mathrm{~g} / \mathrm{L}, 0.05 \mathrm{~A} / \mathrm{cm}^{2}$, stirring rate \#2. 


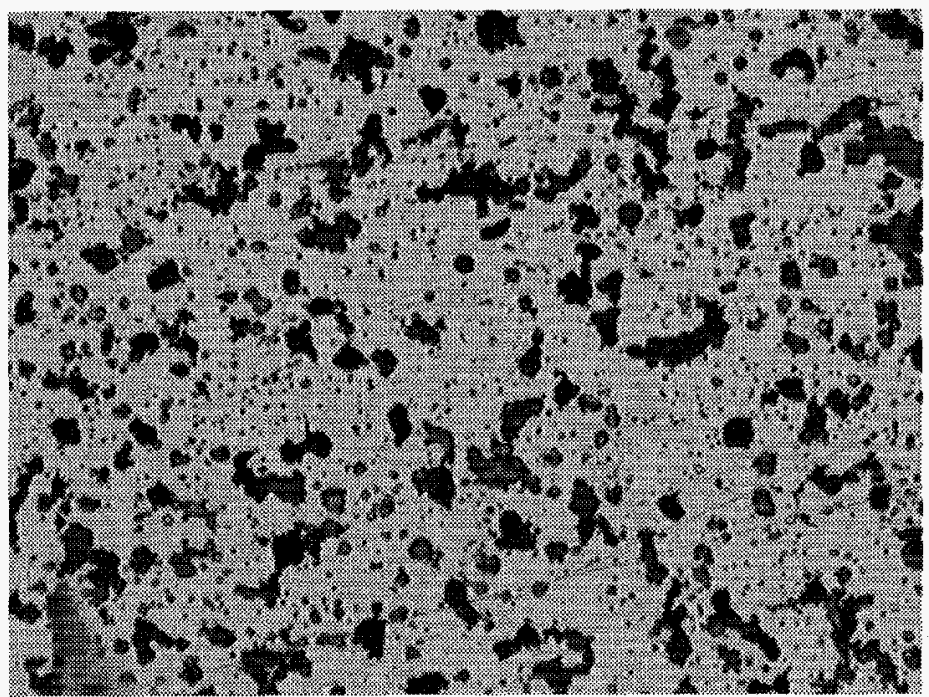

Fig. 6(a). SB03 center of electrode with extensive pitting, little surface etching (x200): $600 \mathrm{~g} / \mathrm{L} \mathrm{NaNO}_{3}, \mathrm{pH}=7, \mathrm{Cr}^{+6}=0.02 \mathrm{~g} / \mathrm{L}, 0.3 \mathrm{~A} / \mathrm{cm}^{2}$,

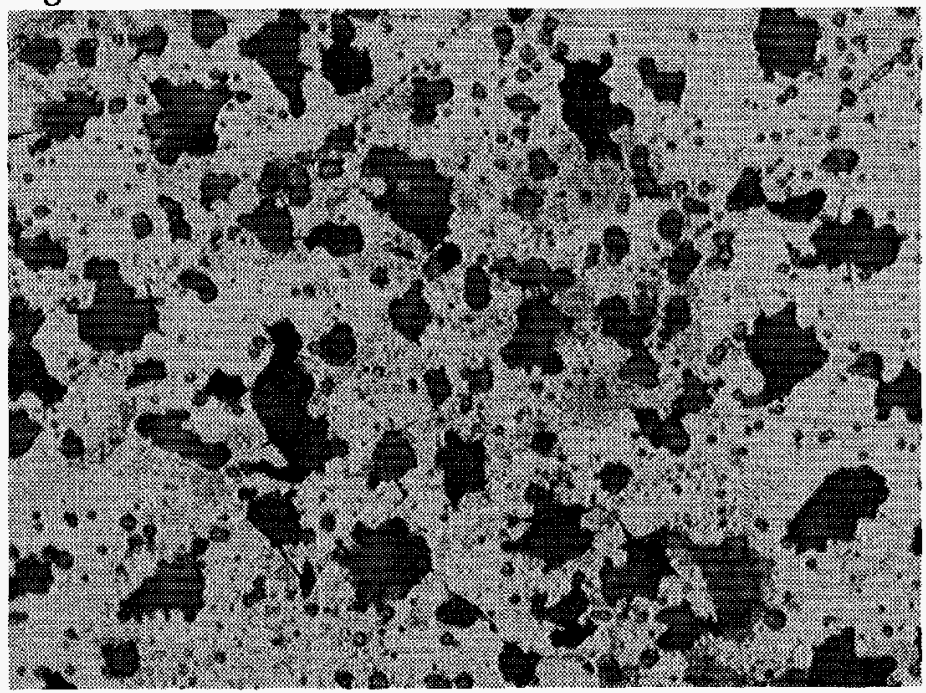

Fig. 6(b). SB04 center of electrode with multiple shallow and deep pits, many 30-60 $\mu \mathrm{M}$ deep, little surface etching (x200): $600 \mathrm{~g} / \mathrm{L}$ $\mathrm{NaNO}_{3}, \mathrm{pH}=7, \mathrm{Cr}^{+6}=0.03 \mathrm{~g} / \mathrm{L}, 0.3 \mathrm{~A} / \mathrm{cm}^{2}$, stirring rate \#2.

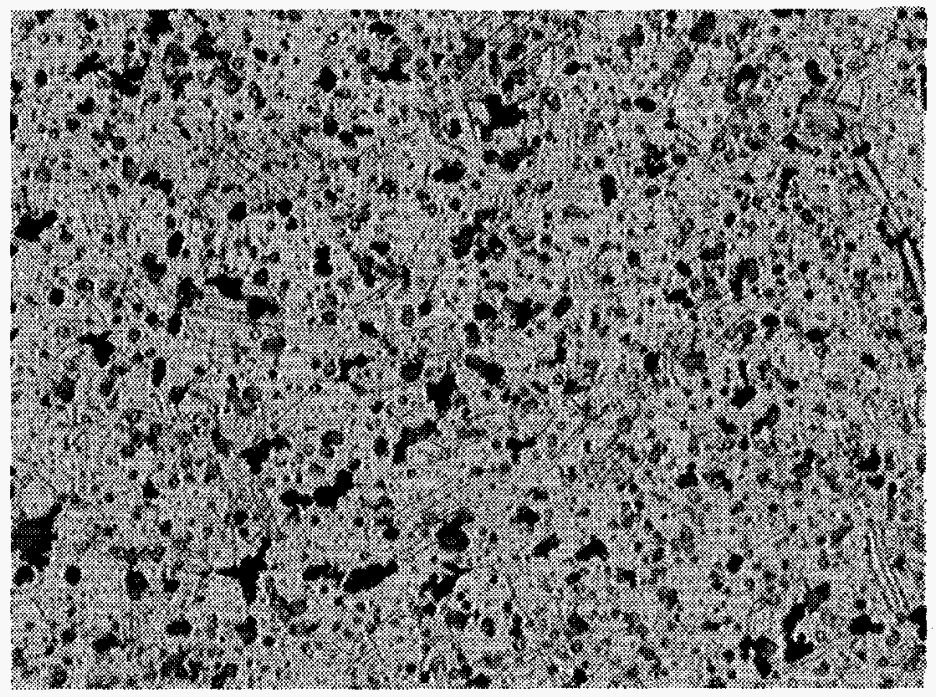

Fig. 6(c). SC02 center of electrode with surface etching and shallow pitting around $15 \mu \mathrm{M}$ deep (x200): $200 \mathrm{~g} / \mathrm{L} \mathrm{NaNO}_{3}, \mathrm{pH}=7$, $\mathrm{Cr}^{+6}=0.004 \mathrm{~g} / \mathrm{L}, 0.3 \mathrm{~A} / \mathrm{cm}^{2}$, stirring rate \#2.

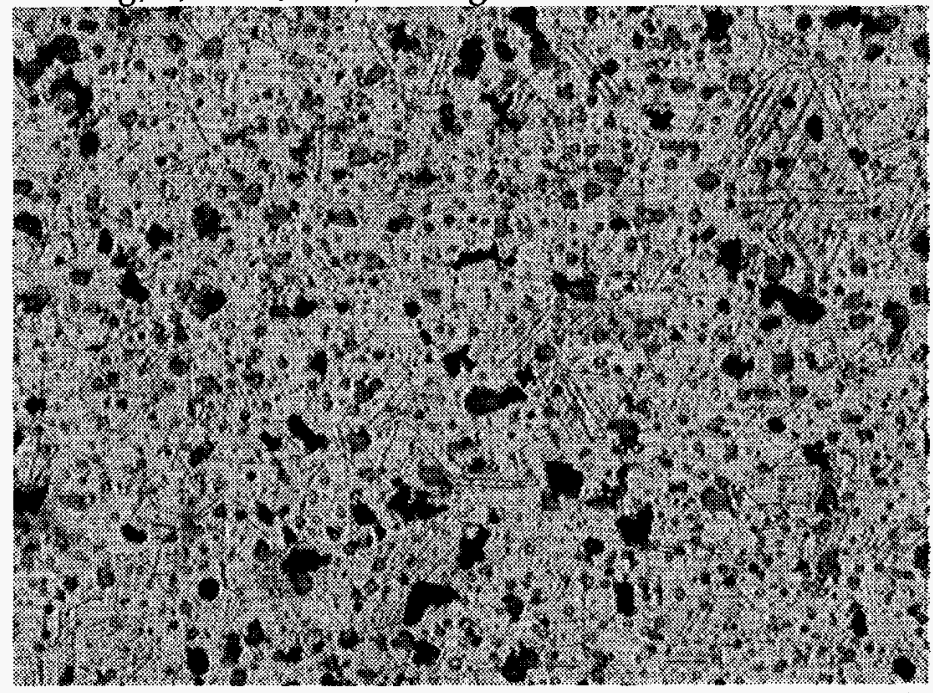

Fig. 6(d). SC07 center of electrode with surface etching and shallow pitting around $15 \mu \mathrm{M}$ deep (x200): $200 \mathrm{~g} / \mathrm{L} \mathrm{NaNO}_{3}, \mathrm{pH}=10$, $\mathrm{Cr}^{+6}=0.04 \mathrm{~g} / \mathrm{L}, 0.3 \mathrm{~A} / \mathrm{cm}^{2}$, stirring rate \#2. 

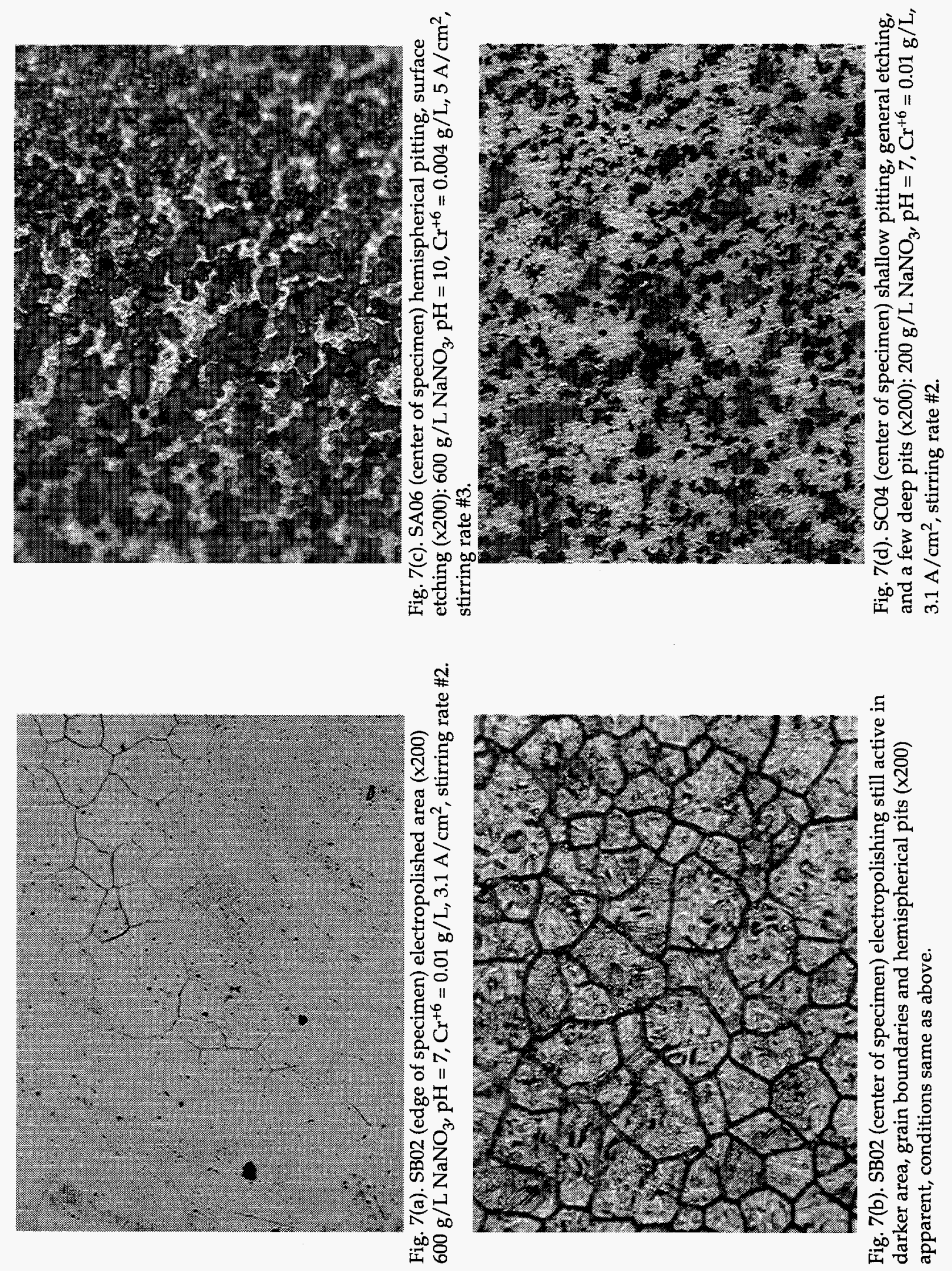


\section{Weld Zone Electrodissolution}

We observed that approximately twice as much material was removed from the cans with exposed weld zones. The exposed weld zones were attacked very aggressively and the resulting surface texture was highly pitted. The affected weld zones were approximately $1 / 4$-in. wide along the rim of the cans. This corresponds to half of the mass removed from about $6 \%$ of the total surface area.

Material removal from the can surface appeared to be in the etching mode. The mass dissolution rate from the can surface was $0.036 \mathrm{mg} / \mathrm{cm}^{2} / \mathrm{min}$ compared with $0.547 \mathrm{mg} / \mathrm{cm}^{2} / \mathrm{min}$ along the weld zones. For the duration of our tests, the trend for mass removal as a function of time for both conditions was linear. Test results are summarized in Fig. 8.

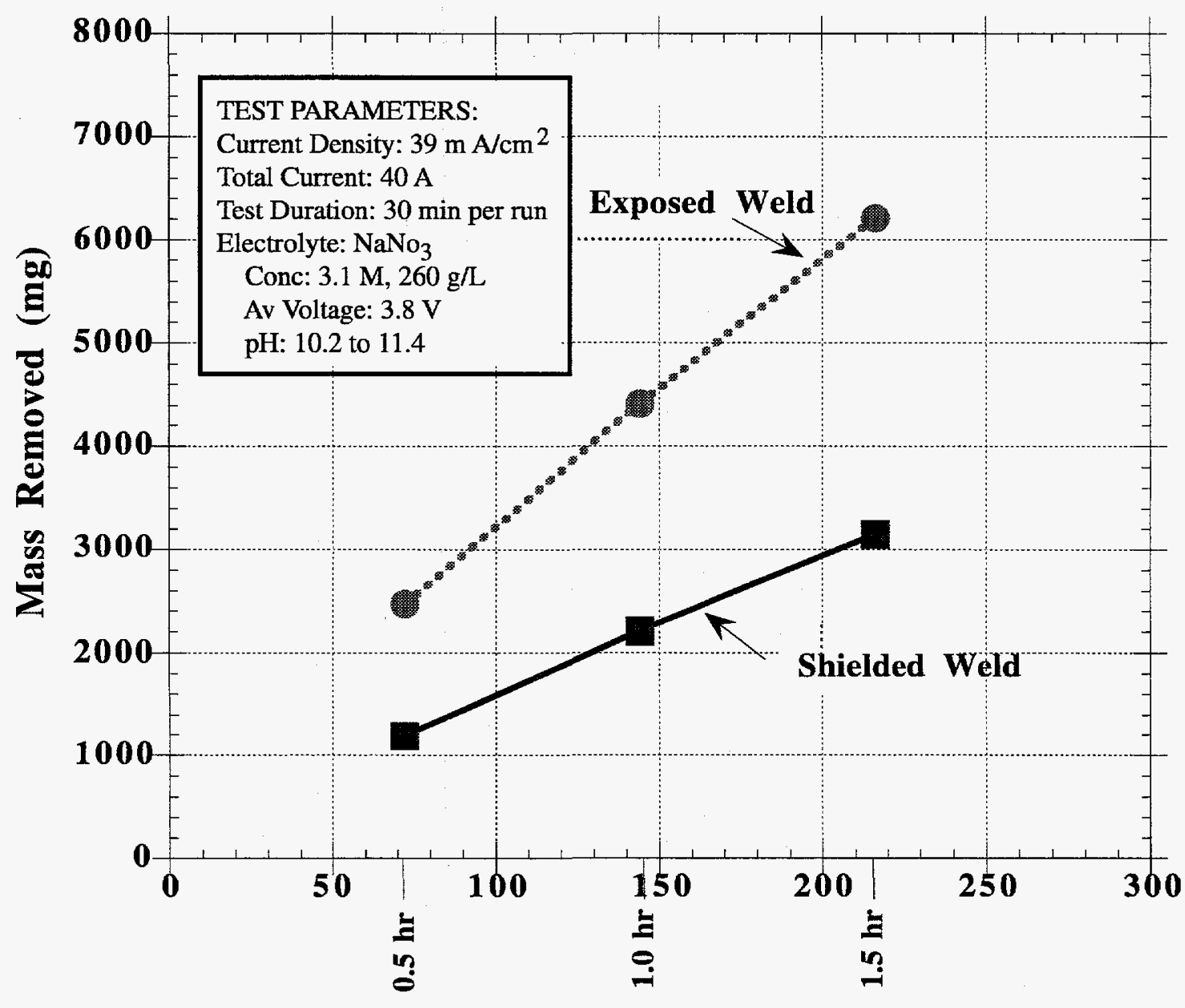

$\mathbf{C} / \mathbf{1 0 0 0}$

Fig. 8. Relative rates of dissolution of whole can and weld zones in sodium nitrate electrolyte. 
Current efficiency for the tests with shielded weld zones was about $9 \%$ compared with $17 \%$ when the welds were exposed. Both values are lower than $20-30 \%$ current efficiency seen in beaker tests at approximately the same current density and concentrations. The reason for the difference between the two test configurations is unclear.

The mechanism for enhanced mass removal on the weld zone is not completely understood. However, based on beaker tests with coupons of similar geometry, we believe that the change in the electric field at the corner is not a significant factor. It appears that the metallurgy of welded regions leads a higher surface energy which improves dissolution kinetics.

\section{IMPLICATIONS}

We explored a wide range of operating parameters for the nitrate system. Classical electropolishing is only reached in the nitrate system at current densities above $1 \mathrm{~A} / \mathrm{cm}^{2}$. Because of the large area of the cans $\left(\sim 1000 \mathrm{~cm}^{2}\right)$ and limited power feedthroughs generally available in gloveboxes, the corresponding currents do not appear to be practical.

We obtained the next-best finish at approximately $0.05 \mathrm{~A} / \mathrm{cm}^{2}$ at lower electrolyte concentrations. While we obtained reasonable finishes, preferential attack at the welds is apparent. Another concern we had with the nitrate system is the added complexity of an electrolytic method to reduce $\mathrm{Cr}^{+6}$ for removal. Ferrous sulfate or sodium bisulfite may be used in the sulfate system without contamination of the electrolyte. In contrast, chemical reducing agents in the nitrate system contaminate the electrolyte.

Concurrent to our development work on the nitrate system, the sulfate system was being explored under the direction of the Laboratory's Doug Wedman. Tests using the sulfate system show that a $0.2-\mathrm{M}(26.4 \mathrm{~g} / \mathrm{L})$ solution does not show preferential attack of weld zones. In addition, numerous chemical reducing agents for chromium are available that do not contaminate a sulfate bath. Therefore, we recommend that the sulfate electrolyte system be developed further. 


\section{REFERENCES}

1. D. E. Wedman, H. E. Martinez, and T. O. Nelson, CHEMTECH, April, pp. 26-29 (1996).

2. H. E. Martinez, Summary of Electrolytic Decontamination of a Polished 304 Stainless Steel Storage Can, internal communication, January 1996.

3. John Huang, Los Alamos National Laboratory, personal communication, February 8, 1996.

4. T. P. Hoar, D. C. Mears, and G. P. Rothwell, Corrosion Sci. 5, pp. 279-285 (1965).

5. K. W. Mao, M. A. Laboda, and J. P. Hoare, J. Electrochem. Soc. 119, pp. 419-427 (1972).

6. E. L. Childs and J. R. Winkel, Nucl. Technol. 63, pp. 271-285 (1983).

7. J. Newman, Electrochemical Systems, (Prentice Hall, Englewood Cliffs, N.J., 1973), pp. 345-350.

8. M. Datta and D. Landolt, Electrochemica Acta, 25, pp. 1263-1271 (1980). 